\section{Jurnal \\ Teknologi \\ CONTINUOUS USE OF ONLINE StORAge SyStem FOR DOCUMENT SHARING}

Fadhilah Mat Yamina*, Wan Hussain Wan Ishak ${ }^{b}$

aSchool of Technology Management \& Logistics, College of Business, Universiti Utara Malaysia, 06010, Kedah, Malaysia bSchool of Computing, College of Arts and Sciences, Universiti Utara 06010, Kedah, Malaysia
Article history

Received

02 June 2015

Received in revised form

09 August 2015

Accepted

1 September 2015

*Corresponding author fmy@uum.edu.my

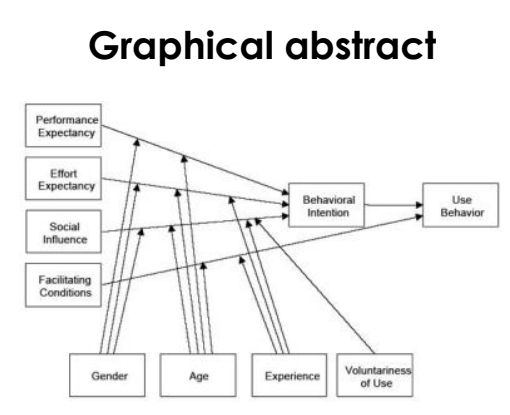

\begin{abstract}
This paper discusses the use of online storage for document sharing to support teaching and learning purposes. To date, online storage has become one of important tools for document storage and management. Online storage has reduced the dependency to the storage devices that are bound to size limit, cost and risk. A part of the storage capability, online storage can be used to share documents by allowing others to access the individual or a group of documents. In this study online storage namely Dropbox has been used to share digital media such as notes, presentation materials and handouts to students. Thus, the use of printed materials can be reduced. In addition the documents can be safely kept and access at any time and location that are connected to the internet. This study adapted Unified Theory of Acceptance and Use of Technology (UTAUT) to assess students' perception and continuous use of Dropbox towards document sharing. The findings revealed that students have positive perception towards Dropbox. Furthermore, students have indicated that they are keen on continue using the Dropbox to support their learning.
\end{abstract}

Keywords: Online storage system; dropbox; e-learning; acceptance model; unified theory of acceptance and use of technology; document sharing.

(C) 2015 Penerbit UTM Press. All rights reserved

\subsection{INTRODUCTION}

Cloud computing technology has reduce the constraint of space, storage and processor, thus make it "unlimited" to everybody. The online storage can be used to store and backup documents, automatically synchronized the content, and content management facility to manage the content online. Various online storage has been introduced such as Google Drive, Mankayia, JustCloud., OpenDrive, MyDrive, Dropbox, and many more. A review by Stevens [1] shows that each online storage offer different set of features with a storage space up to 10TB. Stevens suggest four important features when choosing online storage: backup \& restore feature, security, mobile access, and help \& support. These features are considered vital to secure, protect and easy access to the documents from any location. Online storage has potential to be used in conjunction to the traditional storage method that relies on the storage devices. Storage devices are traditional prone to virus, damage, missing, limited space, high cost and etc.

In teaching and learning, online storage can be utilized as a tool for document or file sharing. In this paper document sharing is define as the practice of distributing or allowing access to the digital media through internet facility. Through online storage, digital media such as notes, presentation materials and handouts can share to students. Therefore, the use of printed materials can be reduced. The lecturer can benefit from the storage and retrieving features of the online storage where the documents 
can be safely kept and access at any time and location.

In this paper we assess students' acceptance and continuous use of online storage as an alternative tool for document sharing. Formally, we are using document sharing feature in Learning Management System to upload and share documents with students $[2,3]$. This initiative is a part of our effort to utilize internet to support e-learning initiative in conjunction to traditional classroom. Furthermore, our previous study has shown that students are actively use internet for their learning purposes [4].

\subsection{TECHNOLOGY ACCEPTANCE MODEL}

Student acceptance on document sharing through online storage is vital as this technology is relatively new thus, the security is what most concern [5]. The student acceptance to online storage is crucial as it reflect the student's behaviour, attitude and belief. According to Wixom and Todd [6] technology acceptance model can be used to predict technology usage better compare to satisfaction model. This can be achieved by linking behaviours to attitudes and beliefs.

Many technology acceptance models have been introduced by researchers from various fields of study. Masrom and Hussein [7] reviewed several wellknown technology acceptance models namely Theory of Reasoned Action (TRA), Theory of Planned Behaviour (TPB), Technology Acceptance Model (TAM), Unified Theory of Acceptance and Use of Technology (UTAUT), and Innovation Diffusion Theory (IDT). The models are summarized in Table 1.

Table 1 Summary of the technology acceptance models

\begin{tabular}{|l|l|l|l|}
\hline Model & Pioneer & Year & Description \\
\hline $\begin{array}{l}\text { Theory of } \\
\text { Action (TRA) }\end{array}$ & $\begin{array}{l}\text { Martin } \\
\text { Fishbein and } \\
\text { Icek Ajzen }\end{array}$ & 1975 & $\begin{array}{l}\text { An individual } \\
\text { behaviour such as } \\
\text { use or rejection of } \\
\text { technology is } \\
\text { determined by } \\
\text { one's intention to } \\
\text { perform the } \\
\text { behaviour that is } \\
\text { influenced jointly } \\
\text { by the individual } \\
\text { attitude and } \\
\text { subjective norm. }\end{array}$ \\
\hline $\begin{array}{l}\text { Theory of } \\
\text { Planned } \\
\text { Behaviour } \\
\text { (TPB) }\end{array}$ & Icek Ajzen & 1985 & $\begin{array}{l}\text { Actual behaviour } \\
\text { is preceded by } \\
\text { behavioural } \\
\text { intention which is } \\
\text { influenced by } \\
\text { either attitude, } \\
\text { subjective norm, } \\
\text { or perceived } \\
\text { behavioural } \\
\text { control or all of } \\
\text { the factors. }\end{array}$ \\
\hline
\end{tabular}

\begin{tabular}{|l|l|l|l|}
\hline $\begin{array}{l}\text { Technology } \\
\text { Acceptance } \\
\text { Model (TAM) }\end{array}$ & $\begin{array}{l}\text { Fred Davis } \\
\text { and Richard } \\
\text { Bagozzi }\end{array}$ & 1989 & $\begin{array}{l}\text { Individual's of a } \\
\text { adoption of } \\
\text { technology is } \\
\text { dependent on } \\
\text { their perceived } \\
\text { ease of use and } \\
\text { perceived } \\
\text { usefulness of the } \\
\text { technology }\end{array}$ \\
\hline $\begin{array}{l}\text { Innovation } \\
\text { Diffusion } \\
\text { Theory (IDT) }\end{array}$ & Everett Rogers & 1962 & $\begin{array}{l}\text { Explain how, why, } \\
\text { and at what rate } \\
\text { new ideas and } \\
\text { technology } \\
\text { spread through } \\
\text { cultures }\end{array}$ \\
\hline $\begin{array}{l}\text { Unified } \\
\text { Theory of } \\
\text { Acceptance } \\
\text { and Use of } \\
\text { Technology } \\
\text { (UTAUT) }\end{array}$ & $\begin{array}{l}\text { Viswanath } \\
\text { Venkatesh, } \\
\text { Michael G. } \\
\text { Morris, } \\
\text { Gordon B. } \\
\text { Davis, Fred D. } \\
\text { Davis }\end{array}$ & 2003 & $\begin{array}{l}\text { Explain user } \\
\text { intentions to use } \\
\text { an information } \\
\text { system and } \\
\text { subsequent and } \\
\text { usage behavior }\end{array}$ \\
\hline
\end{tabular}

In this study UTAUT model [8] is adapted as it can be used to access students' intentions to use the online storage for document sharing and their subsequent usage. The original UTAUT model is shown in Figure 1. The model holds four key constructs: 1) performance expectancy, 2) effort expectancy, 3) social influence, and 4) facilitating conditions; the first three being direct determinants of usage intention and behavior, and the fourth a direct determinant of use behavior. Gender, age, experience, and voluntariness of use are posited to moderate the impact of the four key constructs on usage intention and behavior. Table 2 explains the four UTAUT variables in context of this study.

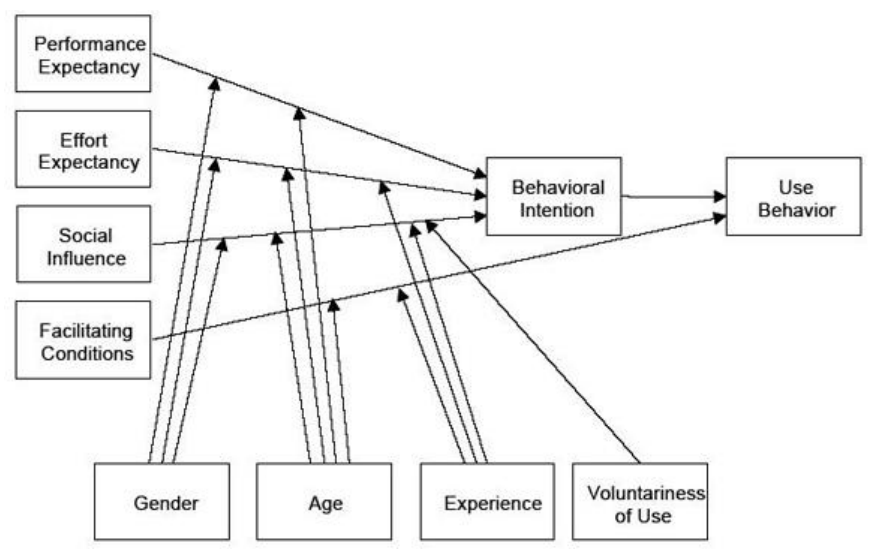

Figure 1: UTAUT original conceptual model 
Table 2: UTAUT variables

\begin{tabular}{|l|l|}
\hline Variable & Explanation \\
\hline $\begin{array}{l}\text { Performance } \\
\text { Expectancy }\end{array}$ & $\begin{array}{l}\text { Students' perception that using the } \\
\text { Dropbox will enhance their productivity, } \\
\text { enable them to accomplish tasks more } \\
\text { quickly, and improve quality of care }\end{array}$ \\
\hline $\begin{array}{l}\text { Effort } \\
\text { Expectancy }\end{array}$ & $\begin{array}{l}\text { Students' perception that it is easy to } \\
\text { learn, become skillful, and use the } \\
\text { Dropbox. }\end{array}$ \\
\hline $\begin{array}{l}\text { Influence } \\
\text { Fhich important other persons in the work } \\
\text { environment approve (or do not approve) } \\
\text { of acceptance and use of the Dropbox. }\end{array}$ \\
\hline $\begin{array}{l}\text { Conditions } \\
\text { Intention }\end{array}$ & $\begin{array}{l}\text { Students' perception of the factors in the } \\
\text { university that impede or facilitate the } \\
\text { acceptance and use of the Dropbox. }\end{array}$ \\
\hline $\begin{array}{l}\text { Use } \\
\text { behaviour }\end{array}$ & $\begin{array}{l}\text { Students' overall affective reaction to } \\
\text { using a Dropbox. }\end{array}$ \\
\hline
\end{tabular}

\subsection{METHODOLOGY}

This study employed purposive sampling method, where the questionnaire with 7 point linkert scale ( $1=$ Totally unacceptable to $7=$ Perfectly acceptable) was distributed to the students that enrolled in three classes that are Database, Introduction to Artificial Intelligence and Logic Programming. In these classes the students are provided with the notes and handouts in both powerpoint and pdf formats. These materials are uploaded into online storage based on certain schedule.

The online storage used in this study is called Dropbox. Dropbox is a cloud-based, automatic, filesynchronization service that's ideal for accessing and sharing data from nearly anywhere. Dropbox has been reviewed and listed as the top seven best cloud storage services in 2014 by Casserly [9] and was recognized as one of the best cloud storage solutions by Duffy [10]. Dropbox can be accessed through multiple operating systems including Windows, Mac OS, and Linux, as well as mobile devices using Android, iOS, and the Blackberry OS.

The total numbers of students from the three classes are 100 students, however the return and usable questionnaire are 80 . Descriptive analyses that are frequencies and percentages were conducted in order to provide richer understanding of the students' perceptions with respect to the four constructs of UTAUT model.

\subsection{FINDINGS}

The findings of this study shows that $70 \%$ of the respondents are female and the rest are male (30\%) (Figure 2). Descriptive analysis was conducted on the students' feedback. The 7-likert scale has been aggregated into three groups that are unacceptable (combine 1st to 3rd scale point), neutral (4th scale point) and acceptable (combine 5 th to 7 th scale point). Table 3 summarizes the results of the descriptive statistics analysis.

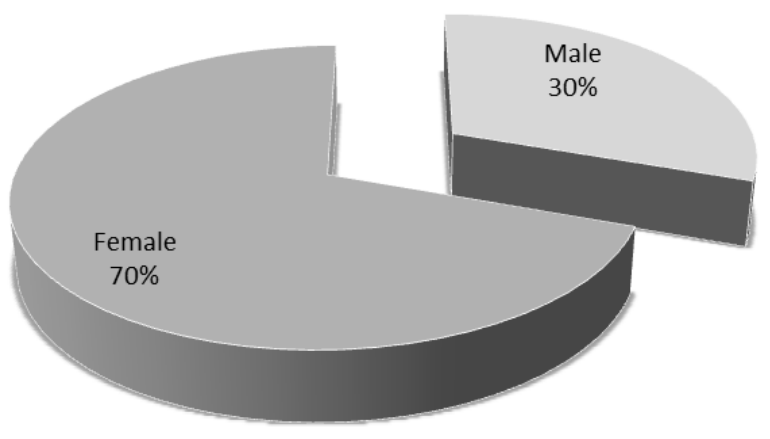

Figure 2: Students' gender 
Table 3 Descriptive statistics ( $n=80)$

\begin{tabular}{|c|c|c|c|c|}
\hline \multirow[t]{2}{*}{ Construct } & \multirow[t]{2}{*}{ Measurement } & \multicolumn{3}{|c|}{ Results } \\
\hline & & $\begin{array}{l}\text { Unacceptable } \\
(\%)\end{array}$ & Neutral (\%) & $\begin{array}{c}\text { Acceptable } \\
(\%)\end{array}$ \\
\hline \multirow{4}{*}{$\begin{array}{l}\text { Performance } \\
\text { expectancy (PE) }\end{array}$} & I find Dropbox useful in my studies & 11.3 & 13.8 & 75 \\
\hline & $\begin{array}{l}\text { Using Dropbox, enable me to accomplish tasks more } \\
\text { quickly }\end{array}$ & 12.6 & 7.5 & 80.1 \\
\hline & Using Dropbox, increase my productivity & 12.6 & 8.8 & 78.9 \\
\hline & $\begin{array}{l}\text { If I use Dropbox, I will increase my chances of } \\
\text { getting a better grade }\end{array}$ & 12.6 & 7.5 & 78.9 \\
\hline \multirow[t]{4}{*}{$\begin{array}{l}\text { Effort } \\
\text { Expectancy (EE) }\end{array}$} & $\begin{array}{l}\text { My interaction with Dropbox is clear and } \\
\text { understandable }\end{array}$ & 11.3 & 10 & 78.8 \\
\hline & It is easy for me to become skilful at using Dropbox & 12.6 & 8.8 & 78.8 \\
\hline & I find Dropbox easy to use & 12.6 & 3.8 & 83.8 \\
\hline & Learning to operate Dropbox is easy for me & 13.9 & 7.5 & 78.8 \\
\hline \multirow{4}{*}{$\begin{array}{l}\text { Attitude toward } \\
\text { using Dropbox }\end{array}$} & Using Dropbox is a good idea & 10.1 & 2.5 & 86.3 \\
\hline & Using Dropbox is bad idea & 56.3 & 10 & 22.6 \\
\hline & Working with Dropbox is fun & 17.5 & 8.8 & 71.4 \\
\hline & I like working with Dropbox & 11.4 & 12.5 & 73.8 \\
\hline \multirow[t]{5}{*}{ Social Influence } & $\begin{array}{l}\text { People who influence my behaviour think that I } \\
\text { should use Dropbox }\end{array}$ & 12.6 & 12.5 & 82.3 \\
\hline & $\begin{array}{l}\text { People who are important to me think that I should } \\
\text { use Dropbox }\end{array}$ & 15.1 & 10 & 75.1 \\
\hline & $\begin{array}{l}\text { The administration of this university has been } \\
\text { supported the use of Dropbox }\end{array}$ & 13.9 & 12.5 & 73.8 \\
\hline & $\begin{array}{l}\text { In general, the university has supported the use of } \\
\text { Dropbox }\end{array}$ & 12.5 & 10 & 77.6 \\
\hline & $\begin{array}{l}\text { My lecturer have been supportive in the use of } \\
\text { Dropbox }\end{array}$ & 8.8 & 3.8 & 87.5 \\
\hline \multirow{4}{*}{$\begin{array}{l}\text { Facilitating } \\
\text { condition }\end{array}$} & I have the resources necessary to use Dropbox & 10.1 & 12.5 & 77.5 \\
\hline & I have the knowledge necessary to use Dropbox & 12.6 & 12.5 & 75.1 \\
\hline & $\begin{array}{l}\text { Dropbox is not compatible with other application I } \\
\text { use (MS word, excel, etc) }\end{array}$ & 36.3 & 12.5 & 51.3 \\
\hline & $\begin{array}{l}\text { A specific person is available for assistance with } \\
\text { difficulties I experience with Dropbox }\end{array}$ & 16.3 & 22.5 & 61.3 \\
\hline \multirow{3}{*}{$\begin{array}{l}\text { Behavioural } \\
\text { intention }\end{array}$} & I intend to use Dropbox in the next days & 8.8 & 11.3 & 80.1 \\
\hline & I predict I will use Dropbox in the next days & 8.9 & 15 & 76.3 \\
\hline & I plan to use Dropbox in the next days & 7.6 & 12.5 & 80.1 \\
\hline
\end{tabular}

\subsection{DISCUSSION}

This study shows that students have positive expectancy on Dropbox towards increasing their performance. The results shows that they tend to believe that Dropbox is a useful (75\%) and productive tool $(78.9 \%)$ for document sharing. The students also believe that Dropbox help them to accomplish their tasks more quickly (80.1\%), thus increase their chances of getting a better grade.

The students also have very strong expectancy that Dropbox is easy to use tool for document sharing. They are strongly agree that Dropbox is easy to understand $(78.8 \%)$, easy to use $(83.8 \%)$, easy to learn $(78.8 \%)$ and easy to become skilful $(78.8 \%)$. This shows that Dropbox has friendly design and fit with students' requirements. Therefore, using Dropbox is not a problem to the students.

The results also reveal that students have positive attitude towards Dropbox. They are strongly agreed that having documents shared through Dropbox $(86.3 \%)$ is a good idea. They also indicate that they like working with Dropbox (73.8\%) and working with Dropbox is fun (71.4\%).

In term of social support, students have positive believe that they are well supported and highly motivated to use Dropbox. The students strongly agree that their lecturer is the most influential and supportive person (87.5\%). Besides the lecturer other people who has influence and important to the students also support them to use the Dropbox $182.3 \%$ and $75.1 \%$ respectively). Moreover, the university and its administration highly support the use of Dropbox to in teaching and learning process (73.8\%).

The students also belief and aware that the university and technical infrastructure does exist to support them when using Dropbox. Students believe that they are provided with necessary resources to use Dropbox (77.5\%). They also agree that they have enough knowledge on how to use Dropbox (75.1\%). In term of technical support, they tend to agree that the technical support staffs are available to assist them (61.3\%).

The results also reveal that the students have strong intention to continue using Dropbox for their learning purposes especially for document sharing. 
Students have positive intention and planning to use the Dropbox in the next days $180.1 \%$ and $80.1 \%$ respectively). Furthermore, students predicted that they will keep on using the Dropbox in their study (76.3\%).

\subsection{CONCLUSION}

Dropbox is easy to install and use by the students. The free version of the software provides services and benefits that are adequately required by the students. Students find it convenient to use Dropbox as document shared through Dropbox will be automatically downloaded and synchronized into their computer. Students were notified when the task has completed.

In term of teaching and learning, Dropbox has found to be one of the useful tools. This study proves that students were positively support the document sharing initiative through Dropbox. This is evident by the students' positive perception towards the construct measured in this study. The findings can be a kind of motivation for the instructor to continue using Dropbox in their teaching. In addition the existence of negative perception among the students on Dropbox can be used as input to plan and improve the method of employing Dropbox for document sharing. The lecturer should consider some of the technical problems such as internet speed and coverage that might affect the use and perception towards Dropbox.

\section{Acknowledgement}

The authors wish to thank the Ministry of education and Research Management \& Innovation Center
(RIMC), Universiti Utara Malaysia for funding this study under RAG Grant Scheme.

\section{References}

[1] Stevens, P. S. 2014. Online Storage Services Review. Retrieved from http://online-storage-servicereview.toptenreviews.com/ on 10 July 2014

[2] Min, K. S., Yamin, F. M., Ishak, W. H. W. 2012. Design, Purpose of Usage and the Impact of LMS on Student Learning: A Preliminary Findings. Proceedings of Knowledge Management International Conference. 673 676.

[3] Yamin, F. M., Ishak, W. H. W., Ibrahim, A. 2014. Students Acceptance on Document Sharing through Learning Management System. Proceedings of 6th International Conference on Education and Information Management. 150-156.

[4] Sian, Y. C., Yamin, F. M., Ishak, W. H. W. 2013. Internet Usage Among Undergraduate Student in Malaysia. Proceedings of Rural ICT Development (RICTD) International Conference. 224-227.

[5] Angeles, S. 2013. 8 Reasons to Fear Cloud Computing. Business News Daily. Retrieved from http://www.businessnewsdaily.com/5215-dangers-cloudcomputing.html on 11 July 2014.

[6] Wixom, B. H., Todd, P. A. 2005. A Theoretical Integration of User Satisfaction and Technology Acceptance. Information Systems Research. 16(1): 85-102.

[7] Masroom, M., Hussein, R. 2008. User Acceptance of Information Technology: Understanding Theories and Models. Malaysia: Venton Publishing

[8] Venkatesh, V., Morris, M. G., Davis, G. B., Davis, F. D. 2003. User Acceptance of Information Technology: Toward a Unified View. MIS Quarterly. 27(3): 425-478

[9] Casserly, M. 2014. 7 Best Cloud Storage Services - 2014's Best Online Storage Sites Revealed. PC Advisor. Retrieved from http://www.pcadvisor.co.uk/features/internet/3506734/b est-cloud-storage-services-review/ on 11 July 2014.

[10] Duffy, J. 2014. The Best Cloud Storage Solutions. PC. Retrieved from http://www.pcmag.com/article2/0,2817,2413556,00.asp on 11 July 2014. 